\title{
Dermoscopic findings of psoriatic nail and their relationship with disease severity
}

\section{Psoriatik tırnağın dermoskopik bulguları ve hastalık șiddeti ile ilișkisi}

Ayșegül Polat, Yelda Kapıcıoğlu*

Edirne Sultan 1. Murat State Hospital, Clinic of Dermatology, Edirne, Turkey *Inönü University Faculty of Medicine, Department of Dermatology, Malatya, Turkey

\begin{abstract}
Background and Aim: The use of dermoscopy in nail diseases is quite recent. Dermoscopy allows a better visualisation of abnormalities of the nail bed and matrix in case of atypical clinical features in psoriatic nail. This study aimed to determine the frequency of findings in psoriatic nail by dermoscopic examination, to compare dermoscopy with clinical examination and to investigate the relationships between the indicators of disease severity.

Materials and Methods: This study included 40 patients who presented with psoriatic nail. The severity of skin involvement of the disease was determined by the Psoriasis Area Severity Index (PASI) and the severity of nail involvement was determined by the Nail Psoriasis Severity Index (NAPSI). Patients' nails were evaluated both by clinical examination and dermoscopy.

Results: The most common clinical and dermoscopic findings were pitting (92.5\%) and leukonychia (92.5\%), respectively. No statistically significant difference was observed between the clinical and dermoscopic NAPSI scores ( $p>0.05)$. No statistically significant relationship was noted between the PASI and the clinical and dermoscopic NAPSI scores ( $p>0.05)$. Dermoscopically, dilated, extended capillary vessels were observed in the nail bed but without the evidence of a relationship with disease severity. A positive correlation was noted between the duration of the disease and the duration of nail involvement $(p<0.05)$. There was a statistically significant positive relationship between the duration of nail involvement and the clinical and dermoscopic NAPSI scores $p<0.05$

Conclusion: Nail dermoscopy was considered to be a preferable method as a supportive and non-invasive procedure prior to biopsy in cases of isolated nail involvement where clinical diagnosis of nail psoriasis is suspicious.
\end{abstract}

Keywords: Psoriasis, nail psoriasis, dermoscopy

Öz

Amaç: Dermoskopinin tırnak hastalıklarında kullanımı oldukça yenidir. Psoriatik tırnakta dermoskopi, klinik özellikler tipik olmadı̆ı̆ında tırnak yatağı ve tırnak matriksi anormalliklerinin daha iyi görülebilmesine olanak sağlar. Bu çalışmada, psoriatik tırnaktaki bulguların dermoskopi ile incelenerek sıklı̆ını saptamak, klinik muayene ile dermoskopik muayene yöntemini kıyaslamak ve hastalık şiddet göstergelerinin birbirleriyle olan ilişkilerini incelemek amaçlanmıştır.

Gereç ve Yöntem: Çalışmaya tırnak tutulumu olan 40 psoriazisli hasta alındı. Hastalığın deri tutulumunun şiddeti Psoriazis Alan Şiddet Indeksi (PAŞi), tırnak tutulumunun şiddeti Tırnak Psoriazisi Şiddet Indeksi (NAPSI) ile belirlendi. Hastaların tırnakları hem klinik olarak hem de bilgisayarlı dermoskop ile değerlendirildi.

Bulgular: En sık görülen klinik bulgu pitting $(\% 92,5)$, dermoskopik bulgu lökonişi $(\% 92,5)$ olarak saptandı. Klinik NAPSı ve dermoskopik NAPS। skorları arasında istatistiksel olarak anlamlı fark bulunmadı $(p>0,05)$. PAŞi ile klinik ve dermoskopik NAPSI skorları arasında istatistiksel olarak anlamlı bir ilişki yoktu $(p>0,05)$. Dermoskopik olarak, tırnak yatağındaki kapiller damarların dilate ve uzamış olduğu görüldü, fakat bu bulgunun hastalık şiddeti ile herhangi bir ilişkisi saptanmadı. Hastalık süresi ile tırnak tutulum süresi arasında pozitif bir korelasyon izlendi $(p<0,05)$. Tırnak tutulum süresi ile klinik ve dermoskopik NAPSI skorları arasında pozitif yönde, istatistiksel olarak anlamlı bir ilişki mevcuttu $(p<0,05)$.

Sonuç: Tırnak dermoskopisinin, klinik olarak tırnak psoriazisi teşhisinin şüpheli olduğu izole tırnak tutulumlarında biyopsi öncesi tanıyı destekleyici, non-invaziv bir yöntem olması sebebiyle tercih edilebilir olduğu düşünüldü.

Anahtar Kelimeler: Psoriazis, tırnak psoriazisi, dermoskopi

Address for Correspondence/Yazışma Adresi: Ayşegül Polat MD, Edirne Sultan 1. Murat State Hospital, Clinic of Dermatology, Edirne, Turkey Phone: +90 5309261330 E-mail: aysglplt@gmail.com Received/Geliș Tarihi: 20.02.2017 Accepted/Kabul Tarihi: 15.08.2017

ORCID ID: orcid.org/0000-0003-0705-4549

(c) Copyright 2017 by Turkish Society of Dermatology and Venereology

Turkderm-Turkish Archives of Dermatology and Venereology published by Galenos Yayınevi. 


\section{Introduction}

Nail psoriasis is an important problem affecting patients both functionally and psychologically. Nail involvement is observed in $50-88 \%$ of psoriatic patients with occasional presence of isolated nail psoriasis alone without skin involvement ${ }^{1,2}$. While nail matrix involvement is associated with pitting, red spots in the lunula, crumbling and leukonychia, nail bed involvement is associated with onycholysis, oil spots, subungual hyperkeratosis and splinter haemorrhages ${ }^{1}$. Dermoscopy was first used in the diagnosis of melanoma. With the advancements achieved in the diagnosis of melanoma over time, it became an auxiliary method in the diagnosis of pigmented and non-pigmented skin tumours, inflammatory/infectious diseases, connective tissue disorders and nail and hair disorders $\mathrm{s}^{3-5}$. The literature contains a very limited number of studies that dermoscopically investigated the findings of psoriatic nail. Our study aimed at determining the frequency of dermoscopic findings in psoriatic nail, comparing the dermoscopic examination with clinical examination and investigating the relationships between the indicators of disease severity.

\section{Materials and Methods}

We recruited 40 patients aged 18-65 years who presented to our clinic between 01.12.2013 and 01.06.2014 with the complaint of psoriasis with nail involvement and agreed to take part in the study, after obtaining the Ethics Committee decision no. 2013/167. All patients gave their written consents. Patients with erythrodermic psoriasis, patients in remission following the systemic treatment for psoriasis, pregnant women, and patients with accompanied onychomycosis and additional systemic diseases that could affect nail were excluded. Data on patients, including age, gender, disease duration, accompanying systemic diseases, treatments for other systemic causes, treatments for psoriasis, tobacco/alcohol use and family history, were recorded. Disease severity was determined by the Psoriasis Area Severity Index (PASI). Patients' nails were examined clinically and dermoscopically, Nail Psoriasis Severity Index (NAPSI) scores were calculated and specific and non-specific findings of psoriatic nail and additional findings were recorded. A MoleMax II computer-aided dermatoscope (Derma Medical Systems Handels u. Entwicklungs GmbH, Vienna, Austria) was used for dermoscopic examination and macro and micro images were recorded on computer. In general, the preferred magnification power was 30-fold, but further magnification was used when required.

\section{Statistical Analysis}

For statistical analysis, mean \pm standard deviation (SD) was used to define quantitative data, and number and percentage (\%) were used to define qualitative data. The Shapiro-Wilk test for normality showed a normal distribution for quantitative data ( $p>0.05)$. Unpaired t-test and Pearson's and Fisher's chi-square tests were used for comparison of the groups. The relationship between the variables was tested by Pearson's correlation coefficient and a $p$ value of less than 0.05 was considered statistically significant.

\section{Results}

Seventeen (42.5\%) patients were male and 23 (57.5\%) were female (18 to 65 years, mean age \pm SD: $34.05 \pm 15.9$ ). The average duration of psoriasis was $10.43 \pm 8.39$ years, and the mean duration of nail involvement was $5.86 \pm 7.58$ years.

The mean PASI score, clinical mean NAPSI score and dermoscopic NAPSI score were calculated as 10.61 $\pm 9.03,21.10 \pm 10.88$ and $20.87 \pm 11.52$, respectively. No statistically significant difference was observed between the clinical NAPSI score and the dermoscopic NAPSI score $(p>0.85)$. Higher PASI scores were detected in men compared to women with a statistically significant difference $(p<0.05)$. No statistically significant difference was observed in clinical and dermoscopic NAPSI scores between genders ( $p>0.05)$.

A statistically significant positive correlation was noted between the duration of disease and the duration of nail involvement $(p<0.05)$. There was a statistically significant positive relationship between the duration of nail involvement and the clinical and dermoscopic NAPSI scores $\mathrm{p}<0.05$.

The most common clinical and dermoscopic findings were pitting (92.5\%) and leukonychia (92.5\%), respectively. Common clinical findings were leukonychia (82.5\%), splinter haemorrhage (75\%), onycholysis (67.5\%), oil drop (42.5\%), subungual hyperkeratosis (35\%), crumbling of the nail (17.5\%) and red spots in the lunula (5\%). Common dermoscopic findings included splinter haemorrhage (80\%), pitting (77.5\%), onycholysis (77.5\%), oil drop (47.5\%), subungual hyperkeratosis (32.5\%), crumbling of the nail (20\%) and red spots in the lunula (5\%). Pitting was observed more frequently with clinical examination compared to the dermoscopic method. The difference was statistically significant $(p=0.03)$. Clinical and dermoscopic nail findings observed in the patients are shown in Table 1. Some additional findings which were not included in NAPSI scoring were noted during the

\begin{tabular}{|l|l|l|l|}
\hline $\begin{array}{l}\text { Table 1. Clinical and dermoscopic findings and } \\
\text { percentages }\end{array}$ & n & $\%$ & p value \\
\hline & 37 & $92.5 \%$ & 0.03 \\
\hline $\begin{array}{l}\text { Pitting } \\
\text { Clinical } \\
\text { Dermoscopic }\end{array}$ & 31 & $77.5 \%$ & \\
\hline $\begin{array}{l}\text { Red spots in lunula } \\
\text { Clinical }\end{array}$ & 2 & $5 \%$ & 1.000 \\
Dermoscopic & 2 & $5 \%$ & \\
\hline $\begin{array}{l}\text { Leukonychia } \\
\text { Clinical } \\
\text { Dermoscopic }\end{array}$ & 33 & $82.5 \%$ & 0.21 \\
\hline $\begin{array}{l}\text { Splinter } \\
\text { Clinical }\end{array}$ & 37 & $92.5 \%$ & \\
Dermoscopic & 30 & $75 \%$ & 0.62 \\
\hline $\begin{array}{l}\text { Crumbling } \\
\text { Clinical }\end{array}$ & 32 & $80 \%$ & \\
Dermoscopic & & & \\
\hline $\begin{array}{l}\text { Subungual hyperkeratosis } \\
\text { Clinical }\end{array}$ & 14 & $35 \%$ & 1.00 \\
Dermoscopic & 13 & $32.5 \%$ & \\
\hline $\begin{array}{l}\text { Oil drop } \\
\text { Clinical }\end{array}$ & 17 & $42.5 \%$ & 0.62 \\
Dermoscopic & 19 & $47.5 \%$ & \\
\hline $\begin{array}{l}\text { Onycholysis } \\
\text { Clinical }\end{array}$ & 27 & $67.5 \%$ & 0.12 \\
Dermoscopic & 31 & $77.5 \%$ & \\
\hline
\end{tabular}


clinical and dermoscopic examination. Clinically and dermoscopically, the most common additional findings were longitudinal striations (62.5\%) and capillary prominence at the onychodermal band (67.5\%). The other common additional clinical findings were horizontal striations (7.5\%), periungual splinter (5\%), Beau's lines (2.5\%) and cuticular hyperkeratosis (2.5\%). The other additional dermoscopic findings were longitudinal striations (20\%), periungual splinter (10\%), horizontal striations (7.5\%), Beau's lines (5\%) and cuticular hyperkeratosis (5\%). No statistically significant difference was observed between clinical examination and dermoscopic method with respect to frequency of additional findings ( $p>0.05$ ).

Some dermoscopic findings of the nail are shown in Figure 1, 2, 3.

\section{Discussion}

Dermoscopy can be useful in the evaluation of psoriatic nail when there are no typical clinical features. Dermoscopic findings vary depending on the affected area of the nail. Dermoscopy allows for a more detailed and easy evaluation of superficial abnormalities associated with nail matrix involvement such as pitting and crumbling and findings associated with nail bed involvement e.g. onycholysis, oil spots, subungual hyperkeratosis and splinter haemorrhages ${ }^{5,6}$.

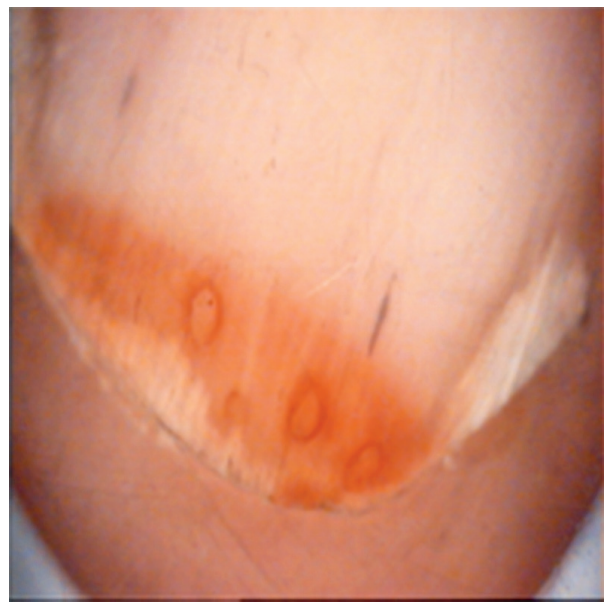

Figure 1. Pitting on nail with henna, splinter haemorrhage, distallateral onycholysis

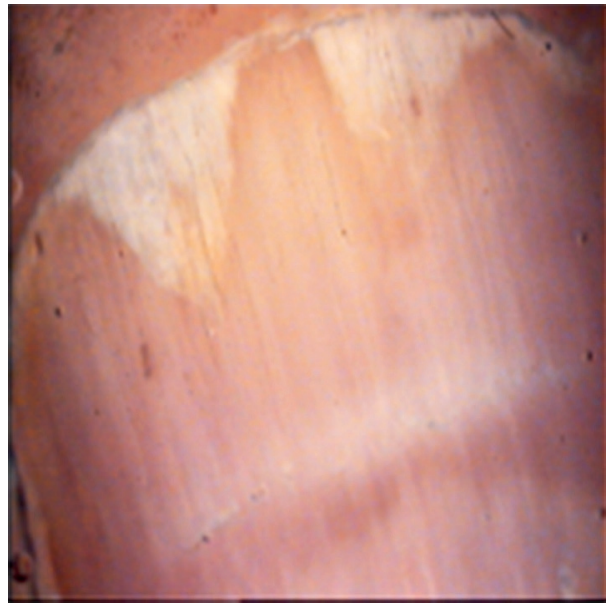

Figure 2. Erythematous border around the onycholytic area, Beau's lines, splinter haemorrhage
Pitting refers to superficial, punctate depressions on the dorsal area of the nail plate which occur due to parakeratosis in the proximal nail matrix. It is deeper and abundant with different sizes in psoriasis compared to that in other disorders. The most common finding observed in studies by Kaur et al. ${ }^{7}$, Tham et al. ${ }^{8}$ and Reich ${ }^{9}$ was pitting (73\%, 68\%, and $75.3 \%$ respectively). Consistent with the literature, we also determined pitting as the most common finding in clinical examination (92.5\%).

Yadav and Khopkar $^{10}$ determined pitting as the most common dermoscopic finding in their study. We observed that pitting was the third most common dermoscopic finding. The difference was statistically significant. Old pitting lesions appear empty as the nail grows distally resulting in desquamation of parakeratotic cells and these gaps may not be viewed in dermoscopy when the glass surface is placed on the lesion or the gel placed in-between may fill up the pittings and prevents the visualisation of concavity in some cases. We believe that the superiority of dermoscopy is decreased as the pittings in psoriatic nail are usually deep. In addition, we interestingly observed that the pittings that we could not observe clinically in some patients due to the use of or contact with exogenous colorants (henna, coal dust, machine oil) could be detected dermoscopically probably owing to staining of concavity.

Leukonychia results from internal desquamation of keratinocytes that could not flake off because of the parakeratosis of the distal nail matrix $^{11}$. Kyriakou et al. ${ }^{12}$ clinically observed leukonychia in $28.9 \%$ of patients. We clinically observed that leukonychia was the second most common finding with an incidence of $82.5 \%$. Notably, we observed leukonychia as the most common finding detected by dermoscopy. No study could be found in the literature on the incidence of dermoscopic finding of leukonychia. In our study, we could ensure a higher visibility for clinically undetectable leukonychic areas by magnification with the dermoscopy method and thus, dermoscopy method was determined to be more efficacious than clinical method, although not statistically significant.

Onycholysis refers to separation of the nail plate from the nail bed $^{13,14}$. Tham et al. ${ }^{8}$ and Kundakci et al. ${ }^{15}$ determined the incidence of onycholysis in psoriatic nail as $67 \%$ and $2 \%$, respectively. Clinically, we found that the incidence of onycholysis was $67.5 \%$. Yadav and Khopkar ${ }^{10}$, in their dermoscopic study, reported onycholysis as the

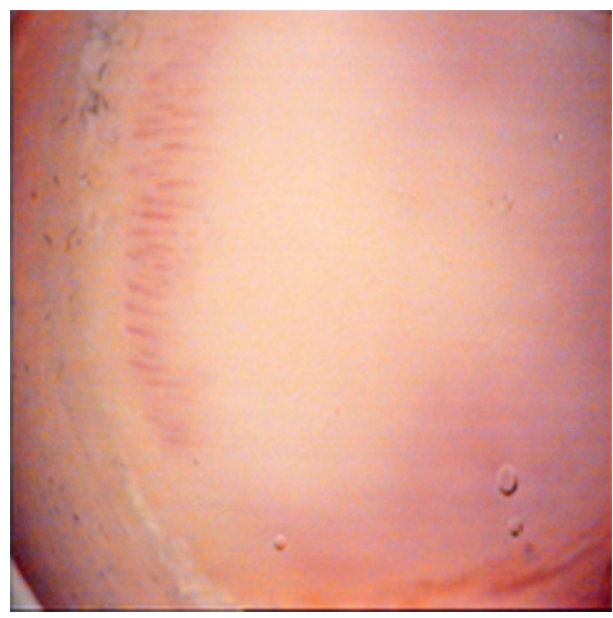

Figure 3. Capillary prominence at the onychodermal band 
second most common finding with the observation of onycholysis in 10 out of 46 patients. We observed that the incidence of onycholysis was $77.5 \%$ by dermoscopy, which was higher than clinical examination, but the difference was not statistically significant. A linear erythematous border around the onycholytic area can be detected, which can be observed via dermoscopy, but not always visible to the naked eye. This finding was considered to be specific to onycholysis observed in nail psoriasis ${ }^{6}$. We also observed this linear erythematous line by dermoscopy in many of the cases (Figure 2). Flaking off of keratinised cells and complete separation of the nail plate and nail bed are necessary to clinically observe onycholysis. We believe that the dermoscopy method can be used to view areas with minimal onycholysis during this period where keratotic cells have not started to flake off and the separation could not be visible to the naked eye.

Oil drop spots are yellowish-pink areas with different sizes resulting from the accumulation of glycoprotein under the nail plate due to the localised involvement of the nail bed. Kyriakou et al. ${ }^{12}$, Salomon et al. ${ }^{16}$ and Kaur et al. ${ }^{7}$ reported the incidence of oil drop spot as $79.6 \%, 12 \%$ and $7 \%$, respectively. Yadav and Khopkar ${ }^{10}$ dermoscopically observed oil drop spot in 2 out of 46 patients. Clinically, we found that the incidence of oil drop spot was $42.5 \%$, while the incidence was $47.5 \%$ with dermoscopic examination. Although not statistically significant, we believe that oil drop spot, a specific sign for clinically missed psoriatic nail, can be observed more easily by dermoscopic examination because of its contrast with the surface.

Examination of the hyponychium and proximal nail fold capillaries is also an effective method for the diagnosis of nail psoriasis and evaluation of, the disease severity and treatment response ${ }^{17}$. A study that investigated proximal nail-fold by capillaroscopy reported a reduced capillary width and density ${ }^{18}$. Iorizzo et al. ${ }^{19}$ investigated the hyponychium in psoriatic patients and observed a capillary pattern of dilated, folded and extended with an irregular distribution and a correlation between the capillary density and the severity of disease. Yadav and Khopkar ${ }^{10}$ observed the capillaries along the onychodermal band as dilated and surrounded by a prominent halo. Yorulmaz and Artuz ${ }^{20}$ also observed dilated, tortuous hyponychial capillaries associated with disease severity. We also detected the capillaries along the onychodermal band as dilated, extended and became prominent (Figure 3). In our study, the capillary prominence was not associated with PASI and NAPSI, which are among the indicators of disease severity.

The pseudo-fiber sign has been described by Yorulmaz and $\operatorname{Artuz}^{20}$ as a novel dermoscopic feature of nail psorasis. They observed red and black filamentous structures located along the cuticle, underneath the distal free edge on the hyponychium or nail plate detached areas. They suggested that this finding was related to nail bed psoriasis and these structures were bare capillaries. There are many studies in the literature that investigated the relationship of nail psoriasis with disease severity ${ }^{9,21-23}$, Radtke et al. ${ }^{23}$ reported that nail psoriasis was associated with severity of psoriasis and poor quality of life. Özden et al. ${ }^{22}$ found a correlation between NAPSI scores and PASI scores. As a different observation, Calvert et al. ${ }^{21}$ reported that patients with severe nail involvement had no severe psoriatic skin lesions. In our study, severe psoriasis was observed in $37.5 \%$ of 40 patients with nail psoriasis. Our patient group rather included patients with mild to moderate psoriasis. Also, no correlation was found between PASI and NAPSI scores.
Dermoscopy has been routinely used in the diagnosis of many inflammatory diseases in the literature. Errichetti et al. ${ }^{24}$ suggested that the psoriatic arthritis without the psoriasis signs and rheumatoid arthritis, which might be clinically confused, could be distinguished by dermoscopic examination of the proximal nail fold and vascular appearance of the elbow and thus, an early diagnosis could be possible for these two diseases by dermoscopy. Nakamura et al..$^{25}$ emphasized that dermoscopy was important as a non-invasive method for early diagnosis of nail lichen planus considering the patient adherence as well as the difficulties with nail biopsy in patients with nail lichen planus.

\section{Conclusion}

We also observed that dermoscopy was useful in early diagnosis of minimal onycholysis, evaluation of clinically indistinguishable onycholysis cases for the presence of linear erythematous border, visualisation of pittings that could not be clinically observed due to the exogenous pigmentation, detection of irregular distribution and the size of these pittings and a better observation of some oil spot and leukonychia cases that are not visible to the naked eye. Specifically, we believe that dermoscopy is a preferable method as a non-invasive procedure prior to biopsy in cases of isolated nail involvement where clinical diagnosis of nail psoriasis is suspicious.

\section{Ethics}

Ethics Committee Approval: The study were approved by the İnönü University of Local Ethics Committee decision no.: 2013/167.

Informed Consent: Consent form was filled out by all participants.

Peer-review: Externally peer-reviewed.

\section{Authorship Contributions}

Surgical and Medical Practices: A.P., Y.K., Concept: A.P., Y.K., Design: A.P., Y.K., Data Collection or Processing: A.P., Y.K., Analysis or Interpretation: A.P., Y.K., Literature Search: A.P., Y.K., Writing: A.P., Y.K.

Conflict of Interest: No conflict of interest was declared by the authors.

Financial Disclosure: The authors declared that this study received no financial support.

\section{References}

1. de Berker DAR, Baran R, Dawber RPR: The Nail in Dermatological Diseases. In: Baran and Dawber's Diseases of the Nails and their Management (Baran R, Dawber RPR, de Berker DAR, Haneke E, Tosti, A, eds), 4th ed. Oxford: Blackwell Science Ltd, 2012:257-80.

2. Tüzün $Y$, Serdaroğlu $S$, Kotogyan A: Tırnağın yapısı. In: Tırnak Hastalıklar (Tüzün Y, Kotogyan A, Serdaroğlu S, Onsun N, eds), İstanbul: Teknografik Matbaası, 1993:9-27.

3. Zalaudek I, Argenziano G, Di Stefani A, et al: Dermoscopy in general dermatology. Dermatology 2006;212:7-18.

4. Lallas A, Zalaudek I, Argenziano G, et al: Dermoscopy in general dermatology Dermatol Clin 2013;31:679-94.

5. Micali G, Lacarrubba F, Massimino D, Schwartz RA: Dermatoscopy: alternative uses in daily clinical practice. J Am Acad Dermatol 2011;64:1135-46.

6. Farias DC, Tosti A, Chiacchio ND, Hirata SH: Dermoscopy in nail psoriasis. An Bras Dermatol 2010;85:101-3.

7. Kaur I, Saraswat A, Kumar B: Nail changes in psoriasis: a study of 167 patients. Int J Dermatol 2001;40:601-3.

8. Tham SN, Lim JJ, Tay SH, et al: Clinical observations on nail changes in psoriasis. Ann Acad Med Singapore 1988;17:482-5.

9. Reich K: Approach to managing patients with nail psoriasis. J Eur Acad Dermatol Venereol 2009;23:15-21. 
10. Yadav TA, Khopkar US: Dermoscopy to detect signs of subclinical nai involvement in chronic plaque psoriasis: A study of 68 patients. Indian J Dermatol 2015;60:272-5.

11. Tosti A, Piraccini BM: Nail disorders. In: Dermatology (Bolognia JL, Jorizzo JL, Rapini RP eds.), 2nd ed. St. Louis, MO: Mosby Elsevier; 2008:1061-77.

12. Kyriakou A, Patsatsi A, Sotiriadis D: Detailed analysis of specific nail psoriasis features and their correlations with clinical parameters: a cross-sectional study. Dermatology 2011;223:222-9.

13. Schons KR, Knob CF, Murussi N, Beber AA, Neumaier W, Monticielo OA: Nail psoriasis a review of the literature. An Bras Dermatol 2014;89:312-7.

14. Polat M, Oztas P, Yalçın B, et al: Evaluation of Nail Findings in Psoriasis Patients. Türkiye Klinikleri J Dermatol 2009;19:68-72

15. Kundakci $N$, Türsen $U$, Babiker $M O$, Gürgey $E$ : The evaluation of the sociodemographic and clinical features of Turkish psoriasis patients. Int $J$ Dermatol 2002;41:220-4

16. Salomon J, Szepietowski JC, Proniewicz A: Psoriatic nails: a prospective clinical study. J Cutan Med Surg 2003;7:317-21.

17. Lencastre A, Lamas A, Sa D, Tosti A: Onychoscopy. Clin Dermatol 2013;31:587-93.
18. Bhushan M, Moore T, Herrick AL, Griffiths CE: Nailfold video capillaroscopy in psoriasis. Br J Dermatol 2000;142:1171-6.

19. Iorizzo M, Dahdah M, Vicenzi C, Tosti A: Videodermoscopy of the hyponychium in nail bed psoriasis. J Am Acad Dermatol 2008;58:714-5.

20. Yorulmaz A, Artuz F: A study of dermoscopic features of nail psoriasis. Postepy Dermatol Alergol 2017;34:28-35.

21. Calvert HT, Smith MA, Wells RS: Psoriasis and the nails. Br J Dermatol 1963;75:415-8.

22. Özden MG, Çelik F, Aydın F, et al: Nail Involvement in Psoriatic Patients and NAPSI-PASI Correlation. Türkiye Klinikleri J Dermatol 2010;20:55-9.

23. Radtke MA, Langenbruch AK, Schafer I, Herberger K, Reich K, Augustin M: Nail psoriasis as a severity indicator: results from the PsoReal study. Patient Relat Outcome Meas 2011;2:1-6.

24. Errichetti E, Zabotti A, Stinco G, et al: Dermoscopy of nail fold and elbow in the differential diagnosis of early psoriatic arthritis sine psoriasis and early rheumatoid arthritis. J Dermatol 2016:43:1217-20.

25. Nakamura R, Broce AA, Palencia DP, Ortiz NI, Leverone A: Dermatoscopy of nail lichen planus. Int J Dermatol 2013;52:684-7. 